\title{
Impact of Public Expenditure on the Economic Growth of Nigeria: 1981-2016. A Disaggregated Analysis
}

\author{
Chukwuemeka Nwamuo, Ph.D \\ Department of Economics, Obong University, ObongNtak, Akwalbom state - Nigeria
}

\begin{abstract}
The study investigated the impact of public expenditure on the economic growth of Nigeria: A disaggregated analysis. Annual time series data were obtained from the Central Bank of Nigeria Statistical Bulletin for the period 1981 to 2016 on the variables used for the study. Unit root test was conducted using Augmented Dickey-Fuller test technique and the result showed that the variables were stationary though at different levels. Co-integrated test was also conducted using Johanssen co-integration test method and the result showed that the variables in the model are co-integrated meaning that the variables have a long run relationship. The error correction mechanism shows a very high coefficient of multiple determination $\left(\mathrm{R}^{2}\right)$ in both the overparameterized model $(99 \%)$ and the parsimonious model (99\%). The short run regression result shows that all the components of public capital expenditure have a positive impact except public capital expenditure on administration and transfers that have a negative impact on the economic growth of Nigeria while all the components of public recurrent expenditure has a positive impact except public recurrent expenditure on economic services that has a negative impact on the economic growth of Nigeria.. The result from long run dynamic analysis also revealed that both components of capital and recurrent public expenditure have a positive and significant effect on the economic growth of Nigeria. Based on the, it was recommended that government should increase its capital and recurrent expenditure.
\end{abstract}

Keywords: Public expenditure, capital expenditure recurrent expenditure, economic growth

DOI: $10.7176 / \mathrm{EJBM} / 11-18-02$

Publication date:June $30^{\text {th }} 2019$

1.1 Introduction: The state spends on defence, education and other social services. It also spends on servicing national debts, capital investments. Government also spends on its own maintenance as well as other countries and governments. Government or public expenditure is the expenses of the government for its own maintenance and on the society and the economy as a whole (Chinwoke, 2014). It also refers to the expenses which a government incurs for (i) its own maintenance, (ii) the society and the economy and (iii) helping other countries (Bhatia, 2009). Government expenditure according to Likita (1999) is the expenses or cost that government usually incurs for the maintenance of itself as an institution, the economy and the society. Since market mechanism fails to bring about the desired result in the economy, this has forced the government to intervene. This is one of the contributory factors that led to the increasing state expenditure (Likita, 1999). Government expenditure is made up of capital and recurrent expenditure. Capital expenditure includes all investment in infrastructural projects, physical assets that are for long term purpose mainly to improve the living conditions of the citizens and this includes housing, road construction, agriculture and water resources (Likita, 1999). Chinwoke (2014) defined capital expenditure as the expenditures on the acquisition of things of permanent nature. They include all expenditures on public projects such as buildings, construction of roads, bridges and all permanent structures and assets. Likita (1999) sees recurrent expenditure as spending on services to maintain the existing facilities in the economy, including wages and salaries, maintenance of social services and security. Chinwoke (2014) classified major areas of government expenditure in Nigeria to include administration, economic services, infrastructural and social amenities, national security and defence, grants and aids. Likita (1999), classified government expenditure according to the function they performed and these include: general administration, economic services, social and community services and transfers. According to Chinwoke (2014), the effects of public expenditure include: stimulation of production in the economy, economic stabilization, stimulation of research and development in an economy, aiding the development of basic infrastructure and stimulation of economic growth.

1.2 Statement of problem: Nigeria has witnessed an increase in government expenditure. Available statistics shows that the federal government total capital expenditure increased from N6.57 billion in 1981 to N634.79 billion in 2016. At the disaggregated level, this shows that that the federal government capital expenditure on administration, economic services, social community services and transfers increased from N0.72 million, N3.63 million, N1.30 million and N0.92 million respectively in 1981 to N150.35 million, N261.28 million, N79.63 million and N143.53 million respectively in 2016. At the same time, the federal government recurrent expenditure also increased from N4.8 million in 1981 to N4178.59 in 2016. At the disaggregated level, this shows that federal government recurrent expenditure on administration, social and community services, economic services and transfers increased from N0.91 million, N0.29 million, N0.18 million and N3.46 million in 1981 to N1091.35 million, N781.40 million, N257.73 million and N2047.4 million respectively in 2016 (CBN Statistical bulletin, 
2016). Given that one of the primary aims of increases in government expenditure it to stimulate economic growth, this huge increase in government expenditure is expected to generate a corresponding increase in economic growth in Nigeria, unfortunately, increases in government expenditure has not been able to generate a meaningful growth in Nigeria. The study therefore seeks to investigate the impact of government expenditure on economic growth in Nigeria.

\subsection{Objectives of the study}

The broad objective of the study was to investigate the impact of public expenditure on the economic growth of Nigeria. The specific objectives of the study were:

(i) To investigate the impact of public capital expenditure on administration on economic growth in Nigeria

(ii) To examine the impact of public capital expenditure on economic services on economic growth in Nigeria

(iii) To investigate the impact of public capital expenditure on social community services on economic growth in Nigeria

(iv) To examine the impact of public capital expenditure on transfers on economic growth in Nigeria

(v) To investigate the impact of public recurrent expenditure on administration on economic growth in Nigeria

(vi) To examine the impact of public recurrent expenditure on economic services on economic growth in Nigeria

(vii) To investigate the impact of public recurrent expenditure on social and community services on economic growth in Nigeria

(viii) To examine the impact of public recurrent expenditure on transfers on economic growth in Nigeria

\subsection{Hypothesis of the study:}

In order to guide the study, the following null hypotheses were formulated:

$\mathrm{HO}_{1}$ : Public capital expenditure on administration does not have any impact on growth in Nigeria.

$\mathrm{HO}_{2}$ : Public capital expenditure on economic services does not have any impact on economic growth in Nigeria.

$\mathrm{HO}_{3}$ : Public capital expenditure on social and community services does not have any impact on economic growth in Nigeria.

$\mathrm{HO}_{4}$ : Public capital expenditure on transfers does not have any impact on economic growth in Nigeria.

$\mathrm{HO}_{5}$ : Public recurrent expenditure on administration does not have any impact on economic growth in Nigeria

$\mathrm{HO}_{6}$ : Public recurrent expenditure on economic services does not have any impact on economic growth in Nigeria.

$\mathrm{HO}_{7}$ : Public recurrent expenditure on social and community services does not have any impact on economic growth in Nigeria.

$\mathrm{HO}_{8}$ : Public recurrent expenditure on transfers does not have any impact on economic growth in Nigeria.

\subsection{LITERATURE REVIEW}

\subsection{Theoretical literature}

2.1.1 The Wagner's Law/ Theory of Increasing State Activities: The theory states that as per capita income of an economy grows, the relative size of public expenditure grows along with it. As the economy grows there will be increase in the number of urban centers with the associated social vices such as crime which require the intervention of the government to reduce such activities to the barest minimum. Large urban centers also require internal security to maintain law and order. These interventions by the government have cost leading to increase in public expenditure in the economy. Wagner says that there is a positive relationship between the per capita income of the citizens of a country with government spending, that the income elasticity of government expenditure is always greater than one. According to Wagner, there are inherent tendencies for the activities of different tiers of government; federal, state and local government; to increase both intensively and extensively. There was a functional relationship between the growth of an economy and the growth of government activities so that the latter grows faster than that of the economy. This theory was able to explain government expenditure according to functions. In addition, it was able to influence of industrial development of government functions and expenditure. In accordance to the views expressed by Wagner, government functions include: administrative and protective functions, cultural and welfare functions, direct provision of social and public goods etc. (Chinwoke, 2014; Likita, 1999).

2.1.2 Wiseman-Peacock hypothesis: The main thesis of the authors is that public expenditure does not increase in a smooth and continuous manner, but in jerks or step like fashion. At times, some social or other disturbance takes place, creating a need for increased public expenditure which the existing public revenue cannot meet. While earlier, due to an insufficient pressure for public expenditure, the revenue constraint was dominating and restraining an expansion in public expenditure, now under changed requirements such a restraint gives way. The 
public expenditure increases and makes the inadequacy of the present revenue quite clear to everyone. The movement from the older level of expenditure and the taxation to a new and higher level is the displacement effect. The inadequacy of the revenue as compared with the required public expenditure creates an inspection effect. The government and the people review the revenue position and the need to find a solution of the important problems that have come up and agreed to the required adjustments to finance the increased expenditure. They attain a new level of tax tolerance. They are now ready to tolerate a greater burden of taxation and as a result, the general level of expenditure and revenue goes up. In this way, the public expenditure and revenue get stabilized at a new level till another disturbance occurs to cause displacement effect. Thus each major disturbance leads to the government assuming a larger proportion of the total national economic activity. In other words, there is a concentration effect. The concentration effect also refers to the apparent tendency for central government economic activity to grow faster than that of the state and local level governments (Bhatia, 2009).

\subsubsection{Musgrave Theory of Public Expenditure Growth:}

This theory was propounded by Musgrave. He posits that at low levels of per capita income, demand for public services tends to be very low, this is so because according to him such income is devoted to satisfying primary needs and that when per capita income starts to rise above these levels of low income, the demand for services supplied by the public sector such as health, education and transport starts to rise, thereby forcing government to increase expenditure on them. He observes that at the high levels of per capita income, typical of developed economics, the rate of public sector growth tends to fall as the more basic wants are being satisfied (Udofia and Godson, 2016).

\subsubsection{The Keynesian Theory:}

Of all economists who discussed the relation between public expenditures and economic growth, Keynes was among the most noted with his apparently contrasting viewpoint on this relation. Keynes regards public expenditures as an exogenous factor which can be utilized as a policy instrument to promote economic growth. From the Keynesian thought, public expenditure contributes positively to economic growth. Hence, an increase in government consumption is likely to lead to an increase in employment, profitability and investment through multiplier effects on aggregate demand. As a result, government expenditure augments the aggregate demand, which provokes an increased output depending on expenditure multipliers. (Udofia and Godson, 2016).

\subsection{Conceptual literature}

2.2.1 Meaning of public expenditure: Public expenditure refers to all expenditures, both recurrent and capital expenditures which the government incurs in the course of performing its functions (Njoku, 2009). Likita (1999) defined public expenditure as the expenses or cost that government usually incurs for maintenance of itself as an institution, the economy and the society. Bhatia (2009) sees public expenditure as the expenses which a government incurs for (i) its own maintenance, (ii) the society and the economy and (iii) helping other countries. Government expenditure is also called public expenditure. It simply refers to the value of all goods and services provided by the public sector (government). This kind of expenditure is directed towards accelerating economic growth and development with the ultimate aim of transforming the nation into an industrialized economy as well as raising standard of living of the people (Usman and Agbede, 2015). Public expenditure can also be seen as the absorption of resource by the public sector. It involves all the expenses which the public sector incurs for its maintenance, for the benefit of the economy, external bodies and for other countries (Anyanwu, 1997).

2.2.2 Structure of public expenditure: Public expenditure is structured into two major categories which make for easy accounting and efficient fiscal management. The two categories of public expenditure are recurrent expenditure and capital expenditure. Recurrent expenditure are expenditures that occur regularly throughout the year. They must be made regularly if the functions of government must be maintained. They include regular salaries of all employees, money spent on the running of essential services or regular maintenance of infrastructural facilities and money spent on administration. Capital expenditure are all the expenditures on capital projects such as buildings, construction of roads, bridges and all permanent structures and assets. These usually involve large sums of money and also form the basis of the physical development of a nation (Chinwoke 2014).

2.2.3 Classification of public expenditure: public expenditure can be classified according to the functions that they perform. Among these functions are:

(a) General administration: Government spends money on payment of wages and salaries including other running costs, expenses for the maintenance of law and order through internal security such as police and the armed forces that require the necessary equipment internal and external aggression.

(b) Economic services: Government spends money on this sector so as to increase the pace of economic development which in turn will improve the welfare of the citizens. Such expenses include investment in agriculture and water resources, construction, manufacturing industries, mining and quarrying, transport and communication.

(c) Social and community services: Government spends money in providing social amenities or infrastructures which reduces the cost of production in other sectors of the economy. This includes expenses for the establishment 
of schools, health facilities etc.

(d) Transfers: This is the amount of money spent on debt repayment both the principal and the interest, running cost of foreign missions, donations, grants and aid given to other countries. (Likita, 1999).

\subsubsection{Canons of public expenditure}

(i) Canon of economy: Resources are scarce relative to their economic needs. For this reason, public expenditure must be incurred on something which is socially and economically desirable. Public expenditure must be effectively controlled and efficiently managed. No wastages, no misapplication and/or misappropriation of public revenue through public expenditures on frivolous programs or projects, and no un-necessary extra-budgetary activity.

(ii) Canon of sanction: There should be no diversion of public funds rather funds ought to be judiciously used for the purpose for which they have been sanctioned, approved or appropriated.

(iii) Canon of benefit: Public expenditure must be on goods and services that are beneficial to the citizens. It must be such that maximizes the social benefit of the people which conforms to the principle of 'maximum social advantage' in public revenue generation exercise.

(iv) Canon of surplus: Prudence in public expenditure is essential to ensure that government meets its recurrent expenditure out of its recurrent revenue. No deficit financing, no over spending rather, government must endeavor to achieve a moderate surplus

(v) Canon of close watch: Personnel costs and overheads must be kept under close watch to ensure that ghost workers are not in the payroll and that expenditure allocation for overheads is utilized judiciously and for the intended purposes. There must be a constant audit of material and human resources. Records of revenue and expenditure must be properly kept and return expeditiously made to the appropriate controlling units or authorities. (vi) Canon of social relevance: Capital expenditures must be incurred only on programs or projects that have social relevance to the welfare and wellbeing of the people. All projects, particularly loan-backed capital projects must be thoroughly evaluated to test their technical feasibility and financial viability before infecting public revenue on them (Njoku, 2009).

\subsubsection{Effects of public expenditure}

(i) Public expenditure makes for economic stabilization. The economy is prone to fluctuation in income, employment and prices from time to time. During periods of depression, there is the need for a continuous injection of additional purchasing power in the market through stimulation of investment and consumption activities and through direct public investment, which is part of public expenditure. Such a public expenditure is meant to directly add to the effective demand in the market and generate a high value multiplier effect in the economy.. Again, during a boom, the need to curb extra demand arises. This may be done through reduction in public expenditure while maintain the same or slightly raising the level of taxation. Thus taxation would reduce the purchasing power of the people. Therefore, a curtailing of public expenditure would restrain the inflationary pressures.

(ii) Public expenditure stimulates production in the economy. Public expenditure in an economy accelerates the pace and level of economic activities in that economy thus leading to the attainment of higher levels of production and growth. Public expenditure can add to the effective demand directly and thus generate conditions favourable for the market forces to push up production. Public expenditure aids private investments and production through measures which reduce the cost of production or remove particular bottle-necks. Creation and maintenance of social overheads lead to an all-round reduction in the cost of production and improvement in efficiency. This therefore improves production an d profitability.

(iii) Public expenditure can be used to create human skills through education and training. .The federal government through Education Tax Fund (ETF) has developed infrastructures such as class room blocks, laboratories, libraries, computer centers in many tertiary institutions today.

(iv) Public expenditure aids the development of basic infrastructures. This is for the development of selected economic activities, for example roads, electricity, housing, public health etc. With these infrastructures in place, key and basic industries, power irrigation, mines etc are developed. Through these, the economy is provided a firm basis for growth.

(v) Public expenditure stimulates economic growth. Through economic stabilization, stimulation of investment activity and so on, public expenditure maintain a rate of growth which is smooth. Public expenditure plays an active role in developing social overheads, creation of infrastructures in the form of transport and communication facilities, education and training, growth of capital goods industries, research and development, etc. Public expenditure also stimulates savings and capital accumulation. In these ways, public expenditure is expected to affect the pace and level of economic growth in an economy (Chinwoke, 2014.

\subsection{Empirical literature}

Cornelinus, Nkamare and Ogar (2016) examined Government expenditure and its implications on the Nigerian economy. The study's specific objectives were to examine the effect of recurrent expenditure on the growth of Nigeria economy and to examine the link between capital expenditure and the growth of Nigeria economy. In line 
with these objectives, secondary data were sourced from the CBN statistical bulletin and other relevant publication using the desk survey method. The exploratory and ex-post facto designs were used for the study. The data collected were analyzed using the ordinary least square multiple regression technique. Findings from the analysis revealed that recurrent expenditure had a significant relationship on the growth and development of Nigeria economy; capital expenditure had a significant effect on the growth and development of Nigeria economy and finally, aggregate expenditure had a positive impact on the growth of Nigerian economy. On the basis of these findings, it was recommended that government should spend more on security as this will promote investment; also, government should increase its expenditure on economic services such as agriculture, construction, transport, communication, electricity and other economic services and finally, government should increase its spending on transfers such as pensions, gratuities, bursaries and grants etc.

Udofia and Godson (2016) investigated the impact of federal government expenditure on the Nigerian economic growth. The main objective of the study was to ascertain whether there is a relationship between federal government expenditure and economic growth in Nigeria. The study adopted the Ordinary Least Square estimation technique to estimate the model specified using time series data for the period 1981-2014. Real Gross Domestic Product was used as the dependent variable while federal government capital and recurrent expenditures were used as the independent variables. The result from the regression analysis shows that federal government capital and recurrent expenditures have a positive effect on real GDP. The data used in the analysis were gotten from Central Bank of Nigeria (CBN) statistical bulletin. The study recommended that federal government should direct more of its recurrent expenditure towards economic and community services as they accelerate economic growth. The study also recommended proper management of public funds allocated to the agricultural sector and manufacturing industries as they have the potential of raising the nation's production capacity and providing employment for citizens in the country.

Oziengbe (2013) explores the relative impacts of federal capital and recurrent expenditures on Nigeria's economy in the 1980-2011 period. The empirical analysis begins with an investigation of the effect of total government expenditure (GOVEXP) on gross domestic product (GDP) using multiple linear regression analysis. The estimation result provides evidence that strongly supports Ram's growth accounting model. GOVEXP was thereafter disaggregated into capital expenditure (CAPEXP) and recurrent expenditure (RECEXP) and the impacts of these on GDP were investigated by exploiting the co-integration and error correction mechanism. Unit root test results indicate that the variables which were non-stationary in levels became stationary after first differencing. The co-integration test result indicates the existence of a long-run relationship between the variables. The estimated ECM model reveals that the short-run impact of each explanatory variable on GDP was statistically insignificant contemporaneously, but significant with a lag, with RECEXP exerting greater impact than CAPEXP, though the impact of the former was negative while that of the latter was positive. The variance decomposition results indicate that the proportion of forecast error variance of GDP explained by innovations in RECEXP dominates the proportion explained by innovations in CAPEXP in all the periods. The paper recommends, inter alia that larger share of government expenditure should go into provision of infrastructure and other capital projects.

Nworji, Okwu, Obiwuru, and Nworji, (2012) examined the effect of public expenditure on economic in Nigeria for the period $1970-2009$. The tool of analysis was the OLS multiple regression model specified on perceived causal relationship between government expenditure and economic growth. The major objective of this paper is to analyze the effect of public government spending on economic growth in Nigeria based on time series data on variables considered relevant indicators of economic growth and government expenditure. Therefore, time series data included in the model were those on gross domestic product (GDP), and various components of government expenditure. Analysis was based on data extracted from the Statistical Bulletin of the Central Bank of Nigeria. Results of the analysis showed that capital and recurrent expenditure on economic services had insignificant negative effect on economic growth during the study under period. Also, capital expenditure on transfers had insignificant positive effect on growth. But capital and recurrent expenditures on social and community services and recurrent expenditure on transfers had significant positive effect on economic growth. Consequently, the study recommended more allocation of expenditures to the services with significant positive effect.

Kalu, and Raphael, (2016) carried out a study on an empirical analysis of the effect of government expenditure on the economic growth in Nigeria (1981 - 2013). The study adopted the ex-post facto research design using the ordinary least square regression analysis to estimate the model specified. Real Gross Domestic Product (RGDP) was adopted as the dependent variable while government capital expenditure (CAPEXP) and government recurrent expenditure (RECEXP) represent the independent variables. Two hypotheses which flowed from the research questions were tested with the application of Granger Causality Test, Johansen Rank Cointegration Test and Error Correction Mechanism. There is a confirmation of the existence of a long run relationship and an indication that 2 cointegrating vectors exist at 5\% level of significance. From the results, RECEXP Granger Cause RGDP while RGDP Granger Cause RECEXP. CAPEXP Granger Cause RGDP while RGDP Granger Cause CAPEXP. CAPEXT Granger Cause RECEXP while RECEXP does not Granger Cause CAPEXP. Thus, the study 
recommends amongst others, increased investment on the productive sectors of the economy, such as infrastructure, education and health. However, government should plug all leakages that have hitherto hindered effective and commensurate results from government spending in the past.

Egbetunde and Fasanya (2014) analyse the impact of public expenditure on economic growth in Nigeria during the period 1970 to 2010 making use of annual time series data. The study employs the bounds testing (ARDL) approach to examine the long run and short run relationships between public expenditure and economic growth in Nigeria. The bounds test suggested that the variables of interest put in the framework are bound together in the long-run. The associated equilibrium correction was also significant confirming the existence of long-run relationships. Our findings indicate the impact of total public spending on growth to be negative which is consistent with other past studies. Recurrent expenditure however was found to have little significant positive impact on growth. Therefore, government should increase its spending on infrastructure, social and economic activities.

Eba, Obim, Emori and Nkamare (2017) empirically examined the analysis of Government expenditure on the growth of Nigeria economy (1990-2015). Desk survey method was adopted in gathering relevant information on this study. Data were primarily sourced from secondary using Central Bank statistical Bulletin. Ordinary least square of multiple regression techniques was used in analyzing government expenditure impacts on the growth of Nigeria economy. Based on the analysis, capital expenditure had a positive impact on the growth and development of Nigeria economy. Also discovered that, recurrent expenditure was statistically significant to the growth and development of Nigeria economy. The study recommended that government should devise ways of maintaining an effective control to avoid wastage and misappropriation of funds for expenditure purposes. Government expenditure should be encouraged for the benefit of individuals and the entire society. Emerenini and Ihuagba (2014) investigate the relationship between Nigeria's total expenditure and economic growth from 1980- 2012. This study makes a modest contribution to the debates by empirically analyzing the relationship between Nigeria total government expenditure and its contribution to economic growth, using time series data from 1980 to 2012, obtained from the Central Bank of Nigeria Annual Report and Statement of Account and Federal Office of Statistics. It employs the Engle-Granger two step modeling (EGM) procedure to co-integration based on unrestricted Error Correction Model and Pair wise Granger Causality tests. From the analysis, our findings indicate that GDP and total government expenditure are cointegrated in this study. The speed of adjustment to equilibrium is $44 \%$ within a year when the variables wander away from their equilibrium values. Based on the result of granger causality, the paper concludes that a very weak causality exist between the two variables used in this study. Therefore, the policy implication of these findings is that any reduction in total government expenditure would have a negative repercussion on economic growth in Nigeria.

\subsection{Methodology}

Multiple regression analysis was used in the study. Time series data spanning from 1981 to 2016 was sourced from the Central Bank of Nigeria statistical bulletin. The data was analysed using E-views. 9

\subsection{Model specification}

In order to investigate the impact of public expenditure on economic growth, the model for this study is specified thus;

$\mathrm{GDP}=\mathrm{f}($ PCEA, PCEES, PCESC, PCET, PREA, PREES, PRESC, PRET) .... (1)

Where; GDP $=$ Gross Domestic Product (proxy for economic growth)

PCEA = Public capital expenditure on administration

PCEES $=$ Public capital expenditure on economic services

PCESC = Public capital expenditure on social and community services

PCET = Public capital expenditure on transfers

PREA = Public recurrent expenditure on administration

PREES $=$ Public recurrent expenditure on economic services

PRESC $=$ Public recurrent expenditure on social and community services

PRET = Public recurrent expenditure on transfers

The model in its econometric linear form can be written as:

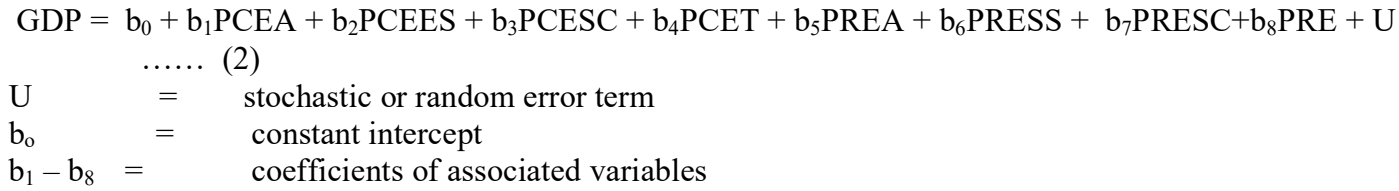

\subsection{Economic a priori expectations}

The economic a priori expectation involves an examination of the signs and magnitude of the estimated parameters to determine their conformity with theoretical expectations. 
Theoretically and from the literature, an increase in government expenditure should lead to a rise in the growth of an economy. Thus the parameters: $b_{1}-b_{8}$ should be positive. This means that all the various forms of government capital expenditure and recurrent expenditures are expected to have a positive effect on the economic growth proxied by gross domestic product.

Since the data for the analysis is time series, the Augmented Dickey-Fuller (ADF) unit root test was employed to ensure data stationarity and avoid the problem of spurious regression. The Johansen test for co-integration was also employed to investigate whether there is existence of long run relationship among the variables in the model. Error correction model was also adopted to determine the rate of adjustment from short run equilibrium to long run equilibrium.

Table 1: Unit root test result

\begin{tabular}{|l|l|l|l|}
\hline Variables & ADF test statistic & $5 \%$ critical value & Order of integration \\
\hline GDP & -3.010300 & -2.96767 & $1(0)$ \\
\hline PCEA & -5.359604 & -2.951125 & $1(1)$ \\
\hline PCEES & -7.337596 & -2.951125 & $1(1)$ \\
\hline PCESC & -4.371846 & -3.580623 & $1(0)$ \\
\hline PCET & -6.301504 & -3.587527 & $1(0)$ \\
\hline PREA & -5.412183 & -2.951125 & $1(1)$ \\
\hline PREES & -5.121059 & -2.951125 & $1(1)$ \\
\hline PRESC & -4.423644 & -3.548490 & $1(1)$ \\
\hline PRET & -7.34984 & -3.548490 & $1(1)$ \\
\hline
\end{tabular}

The unit test result presented on table 1 showed that GDP, PCESC and PCET were stationary at levels while other variables (PCEA, PCEES, PREA, PREES, PRESC and PRET) were stationary at first difference. This is because their various ADF test statistic were greater than their various $5 \%$ critical values in absolute terms.

Table 2: Johanssen co-integration test result

Series: GDP PCEA PCEES PCESC PCET PREA PREES PRESC

PRET

Unrestricted Cointegration Rank Test (Trace)

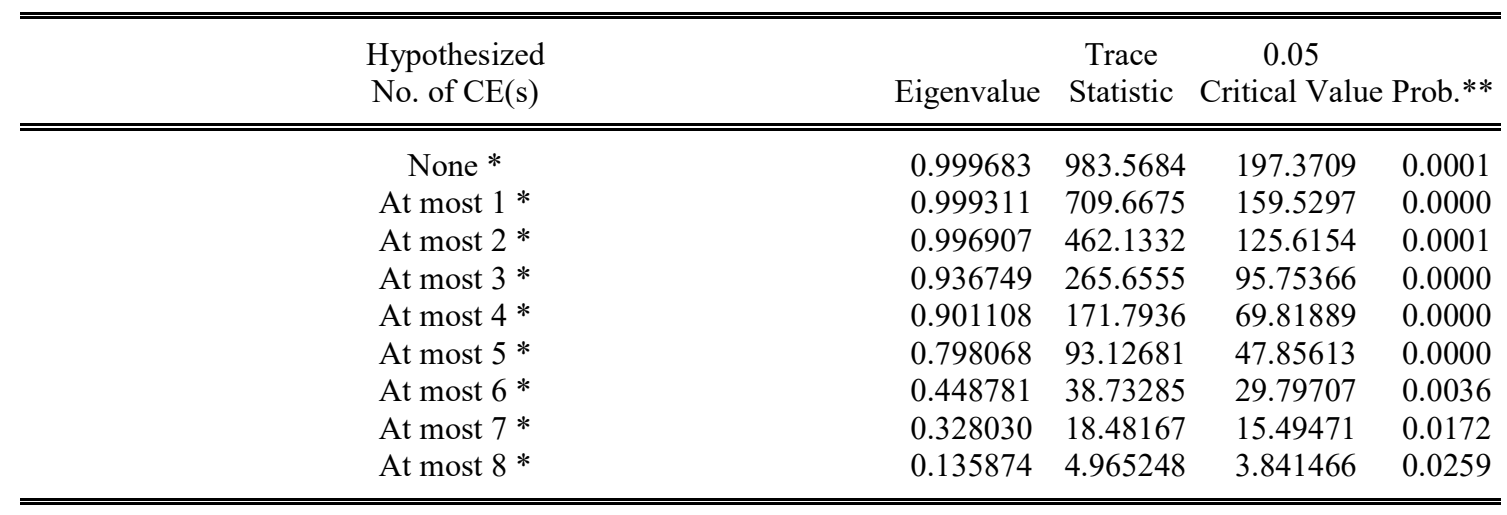

Trace test indicates 9 cointegrating eqn(s) at the 0.05 level

* denotes rejection of the hypothesis at the 0.05 level

**MacKinnon-Haug-Michelis (1999) p-value 
Unrestricted Cointegration Rank Test (Maximum Eigenvalue)

\begin{tabular}{|c|c|c|c|c|}
\hline \multirow{2}{*}{$\begin{array}{c}\text { Hypothesized } \\
\text { No. of CE(s) }\end{array}$} & \multicolumn{4}{|c|}{ Max-Eigen $\quad 0.05$} \\
\hline & Eigenvalue & Statistic & Critical Valu & Prob.** \\
\hline None * & 0.999683 & 273.9010 & 58.43354 & 0.0000 \\
\hline At most $1 *$ & 0.999311 & 247.5342 & 52.36261 & 0.0001 \\
\hline At most $2 *$ & 0.996907 & 196.4777 & 46.23142 & 0.0000 \\
\hline At most $3 *$ & 0.936749 & 93.86190 & 40.07757 & 0.0000 \\
\hline At most $4 *$ & 0.901108 & 78.66682 & 33.87687 & 0.0000 \\
\hline At most $5 *$ & 0.798068 & 54.39396 & 27.58434 & 0.0000 \\
\hline At most 6 & 0.448781 & 20.25118 & 21.13162 & 0.0660 \\
\hline At most 7 & 0.328030 & 13.51642 & 14.26460 & 0.0654 \\
\hline At most $8 *$ & 0.135874 & 4.965248 & 3.841466 & 0.0259 \\
\hline
\end{tabular}

Max-eigenvalue test indicates 6 cointegrating eqn(s) at the 0.05

level

* denotes rejection of the hypothesis at the 0.05 level

**MacKinnon-Haug-Michelis (1999) p-values

The trace test indicates that there was 9 co-integrating equations at 0.05 level. The max-eigen value test also indicates that there were 6 co-integrating equations at 0.05 level. These results showed that the variables are cointegrated. That is, GDP has a long run relationship with PCEA, PCEES, PCESC, PCET, PREA, PREES, PRESC and PRET

The ordinary least square (OLS) result conducted on the specified model is presented on table 3. The OLS result reveals the short run relationship that exists between the dependent variable and each of the explanatory variables.

Table 3. Ordinary Least Square (OLS) Results: Short-Run Analysis

Dependent Variable: GDP

Method: Least Squares

Sample: 19812016

Included observations: 36

\begin{tabular}{|c|c|c|c|c|}
\hline Variable & Coefficient & Std. Error & t-Statistic & Prob. \\
\hline $\mathrm{C}$ & -957.0145 & 961.1702 & -0.995676 & 0.3282 \\
\hline PCEA & -23.47728 & 29.73893 & -0.789446 & 0.4367 \\
\hline PCEES & 0.258000 & 12.00473 & 0.021491 & 0.9830 \\
\hline PCESC & 49.83731 & 52.52239 & 0.948877 & 0.3511 \\
\hline PCET & -2.594157 & 18.32330 & -0.141577 & 0.8885 \\
\hline PREA & 3.009479 & 4.988375 & 0.603298 & 0.5513 \\
\hline PREES & -2.830178 & 12.40055 & -0.228230 & 0.8212 \\
\hline PRESC & 59.30687 & 8.311836 & 7.135232 & 0.0000 \\
\hline PRET & 25.97921 & 3.432163 & 7.569341 & 0.0000 \\
\hline R-squared & 0.989349 & Mean dependent var & & 22394.52 \\
\hline Adjusted R-squared & 0.986193 & S.D. dependent var & & 31287.33 \\
\hline S.E. of regression & 3676.309 & Akaike info criterion & & 19.46952 \\
\hline Sum squared resid & $3.65 \mathrm{E}+08$ & Schwarz criterion & & 19.86540 \\
\hline Log likelihood & -341.4514 & Hannan-Quinn criter. & & 19.60770 \\
\hline F-statistic & 313.5022 & Durbin-Watson stat & & 1.038704 \\
\hline Prob(F-statistic) & 0.000000 & & & \\
\hline
\end{tabular}

From the results of the OLS, the constant parameter (Bo) is negative at -957.0145 This means that if all the independent variables are held constant, GDP as a dependent variable will decrease by 957.0145 units. For PCEA, the coefficient is $-23,47728$. This means that PCEA is negatively related to GDP. This implies that a unit increase in PCEA will lead to 23.47738 units fall in GDP and this is contrary to our aprori expectation. The result also shows that the coefficient of PCEES is positive and this is in agreement with our aprori expectation. The result shows that a unit increase in PCEES will lead to 0.25800 units increase in GDP. The result equally shows that the coefficient of PCESC is positive and this is in agreement with our aprori expectation. From the result a unit increase in PCESC will lead to 49.83730 units increase in GDP. The coefficient of PCET is negative and is contrary 
to our aprori expectation and the result reveals that a unit increase in PCET will lead to a fall in GDP by 2.594157 units while the coefficient of PREA is positive and is in conformity with our aprori expectation. From the result a unit increase in PREA will lead to 3.009479 units increase in GDP. The coefficient of PREES is negative and this contradicts our aprori expectation. The result shows that a unit increase in PREES will lead to 2.830178 units fall in GDP while the coefficient of PRESC is positive and is in conformity with our aprori expectation. The result also shows that a unit increase in PRESC will lead to 59.30687 units increase in GDP.

The next step is to perform the over parameterised and parsimonious error correction method to account for short- run dynamic adjustments required for stable long run relationship among the variables in the model. The over parameterized model is presented in table 3. The over parameterized model account for model misspecification problems as a step towards arriving at a preferred or parsimonious model. This is presented below Table 3 Over-Parameterised Error Correction Results.

Dependent Variable: D(GDP)

Method: Least Squares

Sample (adjusted): 19832016

Included observations: 34 after adjustments

\begin{tabular}{|c|c|c|c|c|}
\hline Variable & Coefficient & Std. Error & t-Statistic & Prob. \\
\hline $\mathrm{C}$ & 97.90332 & 80.18142 & 1.221022 & 0.2409 \\
\hline D(PCEA) & -15.50104 & 6.418158 & -2.415185 & 0.0290 \\
\hline $\mathrm{D}(\operatorname{PCEA}(-1))$ & 30.24826 & 6.002945 & 5.038904 & 0.0001 \\
\hline D(PCEES) & -2.726820 & 1.964274 & -1.388208 & 0.1853 \\
\hline $\mathrm{D}(\operatorname{PCEES}(-1))$ & 1.089308 & 1.695944 & 0.642302 & 0.5304 \\
\hline D(PCESC) & -5.974939 & 5.216992 & -1.145284 & 0.2700 \\
\hline $\mathrm{D}(\operatorname{PCESC}(-1))$ & 24.19431 & 5.363322 & 4.511069 & 0.0004 \\
\hline $\mathrm{D}(\mathrm{PCET})$ & 3.647783 & 2.478681 & 1.471663 & 0.1618 \\
\hline $\mathrm{D}(\operatorname{PCET}(-1))$ & 14.81313 & 2.620441 & 5.652915 & 0.0000 \\
\hline D(PREA) & 0.489159 & 1.227248 & 0.398582 & 0.6958 \\
\hline $\mathrm{D}(\operatorname{PREA}(-1))$ & -2.861185 & 1.278711 & -2.237553 & 0.0409 \\
\hline D(PREES) & -3.283396 & 1.714553 & -1.915016 & 0.0748 \\
\hline D(PREES(-1)) & -5.518204 & 4.985061 & -1.106948 & 0.2858 \\
\hline D(PRESC) & 16.52893 & 1.964307 & 8.414638 & 0.0000 \\
\hline $\mathrm{D}(\operatorname{PRESC}(-1))$ & -11.87373 & 5.059422 & -2.346855 & 0.0331 \\
\hline $\mathrm{D}(\mathrm{PRET})$ & 6.441213 & 1.009939 & 6.377825 & 0.0000 \\
\hline D(PRET(-1)) & -1.793945 & 1.984129 & -0.904147 & 0.3802 \\
\hline $\mathrm{D}(\operatorname{GDP}(-1))$ & 0.859905 & 0.062793 & 13.69433 & 0.0000 \\
\hline ECM(-1) & -0.164670 & 0.063148 & -2.607674 & 0.0198 \\
\hline R-squared & 0.997806 & Mean dependent var & & 2980.427 \\
\hline Adjusted R-squared & 0.995174 & S.D. dependent var & & 3336.063 \\
\hline S.E. of regression & 231.7572 & Akaike info criterion & & 14.02859 \\
\hline Sum squared resid & 805670.7 & Schwarz criterion & & 14.88156 \\
\hline Log likelihood & -219.4861 & Hannan-Quinn criter. & & 14.31948 \\
\hline F-statistic & 379.0441 & Durbin-Watson stat & & 2.516689 \\
\hline Prob(F-statistic) & 0.000000 & & & \\
\hline
\end{tabular}

In the over parameterized model as shown in table 3, the error correction term ECM (-1) is correctly specified. It is negative and statistically significant. This means that it will be effective to correct any deviations from the long-run equilibrium. The coefficient of the ECM(-1) which is -0.164670 indicates that the speed of adjustment to long run equilibrium is 16.5 percent when any past deviation must be corrected in the present period. This means that the present value of GDP adjust rather slowly to changes in PCEA, PCEES, PCESC, PCET, PREA, PREES, PRESC and PRET.

The adjusted $\mathrm{R}^{2}$ in the over parameterized model is 0.995174 . This means that about 99 percent of the variations in the dependent variable (GDP) is explained jointly by the explanatory variables in the model. The Fstatistic of 379.0441 with probability of 0.000000 is highly significant. This means that the explanatory variables in the model (PCEA, PCEES, PCESC, PCET, PREA, PREES, PRESC and PRET) are jointly significant. The Durbin Watson statistic of 2.516689 means the absence of autocorrelation. GDP (-1) is positive and statistically significant. This means that GDP in the one lag period impacts positively and significantly on current period GDP. PCEA in the current period impacts negatively but statistically significant. This contradicts our aprori expectation. The impact of PCEA in the one lag period was positive and statistically significant. PCEES impacts negatively 
and statistically insignificant and this contradicts our aprori expectation while PCEES in the one lag period impacts negatively but statistically insignificant. PCESC impacts negatively and statistically insignificant on GDP and this also contradicts our aprori expectation while the PCESC in the one lag period impacts negatively and significantly on GDP. PCET impacts positively but statistically significant and is in conformity with our aprori expectation while PCET in the one lag period impacts positively and statistically significant on GDP. PREA has a positive and statistically insignificant impact on GDP and this is in conformity with our aprori expectation while the PREA in the one period lag has a negative and statistically significant impact on GDP. PREES and PREES in the one period lag both have a negative and statistically insignificant impact on GDP and this contradicts our aprori expectation. PRESC has a negative and statistically impact on GDP and this contradicts our aprori expectation while PRESC in the one period lag has a negative impact but are statistically significant. PRET impacts positively but statistically significant and is in conformity with our aprori expectation while PRET in the one period lag impacts negatively but statistically insignificant. GDP (-1) impacts positively and statistically significant.

The next step is to perform the parsimonious model which is a stepwise reduction of jointly insignificant variables in the over parameterized model until parsimony is achieved. In other word, the parsimonious model would be built by estimating the equations of only those variables found to be significant in the over-parameterized model. This is presented in table 4

Table 4. Parsimonious Error Correction Result

Dependent Variable: D(GDP)

Method: Least Squares

Sample (adjusted): 19832016

Included observations: 34 after adjustments

\begin{tabular}{|c|c|c|c|c|}
\hline Variable & Coefficient & Std. Error & $\mathrm{t}$-Statistic & Prob. \\
\hline $\mathrm{C}$ & 109.0168 & 71.28831 & 1.529238 & 0.1398 \\
\hline D(PCEA) & -20.79744 & 3.202291 & -6.494551 & 0.0000 \\
\hline $\mathrm{D}(\operatorname{PCEA}(-1))$ & 19.88225 & 3.005385 & 6.615541 & 0.0000 \\
\hline $\mathrm{D}(\operatorname{PCESC}(-1))$ & 23.32286 & 3.202427 & 7.282869 & 0.0000 \\
\hline $\mathrm{D}(\operatorname{PCET}(-1))$ & 14.47661 & 1.005622 & 14.39567 & 0.0000 \\
\hline $\mathrm{D}(\operatorname{PREA}(-1))$ & -1.879587 & 0.433930 & -4.331543 & 0.0002 \\
\hline D(PRESC) & 12.96864 & 1.266731 & 10.23788 & 0.0000 \\
\hline $\mathrm{D}(\operatorname{PRESC}(-1))$ & -9.967592 & 1.559961 & -6.389642 & 0.0000 \\
\hline $\mathrm{D}(\mathrm{PRET})$ & 5.591621 & 0.565075 & 9.895352 & 0.0000 \\
\hline $\mathrm{D}(\operatorname{GDP}(-1))$ & 0.857537 & 0.022970 & 37.33302 & 0.0000 \\
\hline $\operatorname{ECM}(-1)$ & -0.202647 & 0.022332 & -9.074335 & 0.0000 \\
\hline R-squared & 0.994763 & Mean dependent var & & 2980.427 \\
\hline Adjusted R-squared & 0.992487 & S.D. dependent var & & 3336.063 \\
\hline S.E. of regression & 289.1668 & Akaike info criterion & & 14.42808 \\
\hline Sum squared resid & 1923201. & Schwarz criterion & & 14.92190 \\
\hline Log likelihood & -234.2773 & Hannan-Quinn criter. & & 14.59648 \\
\hline F-statistic & 436.9234 & Durbin-Watson stat & & 2.541830 \\
\hline Prob(F-statistic) & 0.000000 & & & \\
\hline
\end{tabular}

In the parsimonious model as shown in table 4, the error correction term ECM (-1) is correctly specified. It is negative and statistically significant. This means that it will be effective to correct any deviations from the longrun equilibrium. The speed of adjustment which is the coefficient of ECM (-1) is -0.202647 . This shows that about 20.3 percent of short run disequilibrium adjusts back to equilibrium in the long run. This indicates that present value of the dependent variable adjusts faster to changes in the independent variables than what is obtained in the over-parameterized model. The adjusted $\mathrm{R}^{2}$ in the parsimonious model is 0.992487 . This means that about 99 percent of the variations in the dependent variable (GDP) is explained jointly by the explanatory variables in the model. The F- statistic of 436.9234 with probability of 0.000000 is highly significant. This means that the explanatory variables in the model - PCEA, PCEES, PCESC, PCET, PREA, PREES, PRESC and PRET - are jointly significant. The Durbin Watson statistic of 2.541830 means the absence of autocorrelation. The result of the parsimonious model also reveals that all the variables in the model are statistically significant. Their significance is determined taking into consideration their probability values. The corresponding probability value of each variable must be less than 0.05 . It can be concluded that changes affecting GDP are determined by PCEA, PCESC,PCET, PREA, PRESC, and PRET. The result of the parsimonious model also shows that the coefficients of PCEA, PREA (-1) and PRESC are negative while the coefficients of PCEA(-1) PCESC(-1) PCET(-1) PRET and GDP(-1) are positive. This implies that The PCEA coefficient of -20.79744 shows that a unit increase in PCEA 
will lead to a decrease in GDP by 20.79744 units. Also, the coefficient of PCEA(-1) at 19.88225 indicates that a positive relationship exist between PCEA(-1) and GDP. A unit increase in PCEA(-1) will lead to 19.88225 unit increase in GDP. The result also shows that a unit increase in PCESC(-1) leads to 22.32286 units increase in GDP while a unit increase in PCET(-1) leads to 14.47661 units increase in GDP. The coefficient of PREA(-1) shows that a unit increase in PREA(-1) leads to 1.879587 units fall in GDP while the coefficient of PRESC shows that a unit increase in PRESC leads to 9.967592 units increase in GDP. The PRET coefficient shows that a unit increase in PRET leads to 5.591621 increase in GDP while the coefficient of GDP(-1) shows that a unit increase in GDP(1) leads 0.857537 units in GDP. The coefficient of the constant (bo) which is 109.0168 shows that if all the explanatory variables are held constant GDP will be 109.0168

\subsection{Summary}

The impact of government expenditure on economic growth of Nigeria for the period $1981-2016$ has been examined in this study. The short run regression result shows that all the components of public capital expenditure were statistically insignificant. With the exception of public capital expenditure on economic services and public capital expenditure on social and community services, all other components of capital expenditure has a negative effect on economic growth. The short run result also showed that all the components of public recurrent expenditure are statistically insignificant except public recurrent expenditure on social services and public recurrent expenditure on transfers which are statistically significant. The result equally revealed that all the components of public recurrent expenditure has a positive effect on the economic growth of Nigeria except public recurrent expenditure on economic services The result of the parsimonious model shows that the various components of public capital expenditure in the one period lag has positive impact on the economic growth of Nigeria while public capital expenditure on the current period has a negative impact on the economic growth of Nigeria. The result also shows that the various components of public recurrent expenditure in the one period lag has a negative impact on the economic growth of Nigeria while public recurrent expenditure in the current period has a positive impact on the economic growth of Nigeria. The joint effect of the explanatory variables on the dependent variable was statistically significant implying that these variables were considered important variables in explaining changes in economic growth proxied by GDP in Nigeria within the period of study. The modeled and operationalized framework of analysis exhibited a very high explanatory power, thereby providing supporting evidence that the explanatory variables included in the model were relevant in explaining changes in economic growth in Nigeria within the period of study.

\subsection{Conclusion:}

Given that the joint effect of the explanatory variables on the dependent variable were statistically significant, the study concludes that the components of government expenditure considered in this study are important variables in explaining economic growth in Nigeria within the period of study.

\subsection{Recommendations:}

Since one period lag of public capital expenditure on administration, public capital expenditure on social and community services and public capital expenditure on transfers have a positive and significant effect on economic growth government should invest more on them for a sustained economic growth and a better future. Moreover, since the current recurrent public expenditure on social and community services and public recurrent expenditure on transfers have a positive and significant effect on the economic growth, government should also increase it expenditure on them as this will help to stimulate economic growth.

\section{REFERENCES}

Anyanwu, J.C (1997). Nigerian Public Finance. Onitsha; Joanee Educational Publishers.

Bhatia, H.L (2009). Public Finance. New Delhi. Vikas Publishing House PVT Ltd.

Chinwoke, N (2014) Public Finance in a developing world. Nigeria; Reconciliation Publishers

Cornelius, M.O; Nkamare, S.O and Ogar, A (2016). Government Expenditure and its Implications on Nigerian Economy. IOSR Journal of Humanities and Social science 21(1) 50-55

Eba, A.O; Obim, E.N; Emori, E.G and Nkumare, S.E (2017) A Disaggregated Analysis of Government Expenditure on the Growth of Nigeria Economy (1990-2015) Research Journal of Finance and Accounting $8(14)$

Egbetunde, T and Fasanya , I.O (2013) Public Expenditure and Economic Growth in Nigeria: Evidence from Auto-Regressive Distributed Lag Specifi cation Zagreb International Review of Economics \& Business 16( 1) $79-92$

Emerenini, F.M and Okezie, A.I (2014) Nigerians Total Government Expenditure: It's Relationship with Economic Growth (1980-2012) Mediterranean Journal of Social Sciences 5(17) 67-78

Kalu, I.A and Rapheal, O.M (2016). An Empirical Analysis of the Effect of Government Expenditure on Economic 
Growth in Nigeria. Research Journal of Finance and Accountinmg 7(20) 60 - 72

Likita, O (1999). Elements of Public Finance. Agege; . Abayomi Industrial packaging ltd

Njoku, P.O (2009). Public Finance: Sources, Administration and Management. Enugu; El 'Demark Publishers.

Nworji, I.D; Okwu, A.T; Obiwuru, T.C and Nworji, L.O (2012). Effects of Public Expenditure on Economic Growth in Nigeria: A disaggregated Time Series Analysis. International Journal of Management Sciences and Business Research 1(7) $226-8235$

Oziengbe, S.A (2013). The Relative Impacts of Federal Capital and Recurrent Expenditures on Nigeria's Economy (1980 - 2011) American Journal of Economics 3(5) 210 - 221

Ufofia, D.T and Godson, J.R (2016). The impact of Federal Government Expenditure on Economic Growth in Nigeria (1981 - 2014). Greener Journal of social sciences 6(4) 92 - 105

Usman, O and Agbede, E.A (2015) Government Expenditure and Economic Growth in Nigeria: A Cointegration and Error Correction Modelin. Munich Personal RePEc Archive 